INDEPENDENT JOURNAL OF MANAGEMENT \& PRODUCTION (IJM\&P) http://www.ijmp.jor.br

V. 11, n. 7, November - December 2020

ISSN: 2236-269X

DOI: 10.14807/ijmp.v11i7.1030

\title{
EFFECT OF PRINCIPALS' RELATIONSHIP MANAGEMENT ON THE ORGANISATIONAL COMMITMENT OF TEACHERS IN SECONDARY SCHOOL IN COUNTY GOVERNMENTS IN KENYA
}

\author{
Nancy Minjire Waweru \\ Jomo Kenyatta University of Agriculture and Technology, Kenya \\ E-mail:waweruwn@gmail.com \\ Hazel Gachunga \\ Jomo Kenyatta University of Agriculture and Technology, Kenya \\ E-mail: hazelgac@yahoo.com \\ John Mwangi Kihoro \\ Co-operative University of Kenya, Kenya \\ E-mail: kihoro.jm@gmail.com \\ Submission: 3/28/2019 \\ Revision: 4/10/2019 \\ Accept: 2/22/2020
}

\section{ABSTRACT}

The purpose of this study was to investigate the influence principals' relationship management (RM) on the organizational commitment (OC) of secondary school teachers in county governments in Kenya as moderated by teachers' selfefficacy. This study hypothesized that principals' RM has no significant relationship on the teachers' OC. Survey research design was employed to establish the relationship between principals' RM and teachers' OC. Simple random sampling was used to draw a sample of 120 principals and 480 teachers from Nairobi, Machakos, Kajiado, and Kiambu counties in Kenya. The method of data collection was through the use of questionnaires. This study established that principals’ RM was a significant predictor of teachers' OC. The study also established that teachers' self-efficacy moderated the relationship between principals’ RM and teachers' OC and that self-efficacy had positive influence on teachers OC. The study recommends that Teachers' Service Commission (teachers' employer) should put more emphasize on training of RM among principals in secondary schools in Kenya. This study makes useful contribution in the advancement of knowledge on the effects of principals’ RM on teachers' OC in Kenya. 
DOI: 10.14807/ijmp.v11i7.1030

Keywords: Relationship Management, Self-efficacy, Organizational Commitment.

\section{INTRODUCTION}

Employees who experience high organizational commitment are theorized to display positive organizational behaviors, such as better job performance, and organizational citizenship activities, which will definitely benefit the organization (ALBDOUR; ALTARAWNEH, 2014).Similarly, organizational commitment also helps to preserve well qualified and talented individuals which lead to the stability of an organization. Committed employees are also less often absent and are less likely to leave the organization voluntarily than the less committed employees.

According to Mowday (1998) committed employees are likely to work harder and more efficiently, and stay in their jobs longer than less committed employees. Therefore, organizations such as schools aspire to have employees who are committed towards the achievement of the organization goals. Newstrom and Davis, (1997) defines organizational commitment as the degree to which an employee identifies with the organization and wants to continue active participation in it. Meyer and Allen (1991) classified employee commitment into three groups namely: affective commitment, continuance commitment, and normative commitment.

Psychologists Mayer and Salovey were the first to use the term emotional intelligence (EI) and are generally credited for performing the first systematic programme of research on EI in the 1990s (MATTHEWS; ZEIDNER; ROBERTS, 2012). Mayer and Salovey (1990) first proposed EI as a subset of social intelligence and defined it as the ability to monitor one's own and others' feelings and emotions, to discriminate among them and to use this information to guide one's thinking and actions. Their concept of EI included three branches consisting of appraisal and expression of emotion, regulation of emotion, and utilizing emotion.

Zeidner, Matthews and Roberts (2004) contends that this is the most widely accepted scientific definition of EI.

Later Mayer and Salovey (1997) expanded their definition of EI to involve the ability to perceive accurately, appraise, and express emotion, the ability to generate feelings when they facilitate thought, the ability to understand emotion and emotional knowledge, and the ability to regulate emotions to promote emotional and intellectual growth. The aim was to exclude elements that had similar personality traits from their previous concept and to include all the abilities represented by EI. 
DOI: 10.14807/ijmp.v11i7.1030

Goleman (2001) came up with five domains of EI which were integrated into the following four (and 20 competencies) domains namely: self-awareness (knowing our own emotions, and knowing how emotions affect the self and others), self-management (knowing our own emotions), social awareness (recognizing the emotions of others), and relationship management (handling relationships).

Self-efficacy was first introduced by Bandura who defined it as the beliefs in one's capacity to organize and execute the courses of action required to produce given attainments (BANDURA, 1997). Recently, self-efficacy has become the focus of attention in the field of teaching since it has been found to be one of the important variables consistently related to positive teaching behavior such as commitment.

According to Adedoyin (2010), efficacious teachers are more likely to stay in teaching, put more time into it and show greater effort in classroom planning and organization and greater enthusiasm for teaching. Similarly, a teacher with a high sense of efficacy portrays more enthusiasm for teaching, has greater commitment to teaching, and is more likely to stay as teachers (TSCHANNEN-MORAN; WOOLFOLK HOY; HOY, 1998).

However some researchers found no correlation between efficacy in teachers and organization commitment. For instance, Murphy (2013) study on the relationship between teacher efficacy and organizational commitment found that teachers' efficacy did not correlate with organizational commitment, and personal teaching efficacy did not correlate with affective commitment.

In this study personal teaching efficacy and general teaching efficacy correlated differently with the factors of organizational commitment and that general teaching efficacy did not correlate with any factors of organizational commitment. This he suggests warrant future investigation into the theoretical perspective of the teacher efficacy and commitment constructs. This study therefore investigated whether principals' RM would affect teachers' OC.

Heading schools is a complex responsibility and principals require more than just IQ and as Goleman (1998b) pointed out EI is the sine qua non of leadership and argue that without it one will not make a great leader. Principals are entrusted with the task of leading their school, making decisions, influencing and guiding the activities of their schools toward achieving their goals. They are responsible for administering all aspects of their school's operations as well as working and improving relationship with the entire school stakeholders such as the students, 
DOI: 10.14807/ijmp.v11i7.1030

teachers, Board of Management, parents, and local community. As they relate with these group they not only have to learn how to manage their emotions but must also manage others emotions.

Tschannen-Moran and Gareis (2004) posits that in this era of accountability and significant school reforms, effort to improve schools look to the principals to spearhead change effort at the school level. While they must attend to myriad administrative tasks they are required to find time to focus on more important issues such as promoting teaching and learning activities in the school since it plays a decisive role for students' success. Self-efficacy determines how long one would persevere in the face of challenges, or how much effort is exerted on a given task (BANDURA, 1997)

\subsection{Problem Statement}

Organizational commitment (OC) has been associated with positive organizational behavior such as decreased employee turnover rate and absenteeism (MEYER; HERSCOVITCH, 2001; SOLINGER; VANOLFFEN; ROE, 2008; TURUNEN, 2011). Over the years however concerns have been raised regarding the lack of commitment among teachers as evidenced by a great number of teachers leaving the profession, frequent industrial actions, a high number of teachers missing school, and others failing to attend class even if they are in school.

A recent study by Kenya National Union of Teachers (2015) indicate that more than 200,000 (807 of them being secondary school teachers or 76 per cent of teachers in public schools wish to leave teaching because of professional needs such as promotion and personal needs which include salaries and allowances. Earlier, report by Machio (2011) indicated that in the year 2008 alone, more than six hundred secondary school teachers left teaching for other jobs as a result of poor pay and conditions of service which is a sign of lack of commitment. When teachers leave the profession there is a potential loss of experienced teachers.

A survey by Teachers' Service Commission (2002) established that 20\% of secondary school teachers miss lessons while in school while only $39.2 \%$ of the teachers are in school every day of the month. When teachers miss school it increases the burden on the part of principal and the deputy principals of handling students' indiscipline as they go unattended.

A teacher who is less committed is likely to put less effort in their work compared to one with high level of commitment. Zeidner, Roberts and Matthews (2002) argue that EI (relationship management included) provides the medium by which educational reforms can 
DOI: 10.14807/ijmp.v11i7.1030

and finally will reach its full potential, across primary, secondary, and tertiary level of school. Employees feel good about working with emotionally intelligent leaders since they are more likely to react to problems in a more controlled manner and may be more accommodative to different views of the subordinates. This study sought to establish whether principals' RM has effects on the OC of secondary school teachers in Kenya.

\subsection{Objectives of the Study}

1) To establish whether principal's relationship management has an effect on the organizational commitment of teachers.

2) To determine the moderating effect of self-efficacy on the relationship between principals' relationship management and organizational commitment of teachers.

\subsection{Research Hypotheses}

- Ho1: There is no significant effect of principal's relationship management on the organizational commitment of teachers.

- $\mathbf{H}_{02}$ : There is no significant moderating effect of self-efficacy on the relationship between principal's relationship management and organizational commitment of teachers.

\section{LITERATURE REVIEW}

\subsection{Relationship Management}

Relationship management refers to managing other people's emotions (GOLEMAN, 2001). It involves being aware of one's emotions and those of others in order to build strong relationships. To be able to manage emotions of others, one must be able aware of his or her emotions, and have the knowledge about emotions. Relationship management is linked to six competencies namely: influence, developing others, inspirational leadership, change catalyst, conflict management, and teamwork and collaboration.

Developing others means sensing what others need in order to develop and bolstering their abilities (GOLEMAN, 2001). People with this competence show genuine interest in the people they are developing as well as understanding their strengths and weaknesses (GOLEMAN; BOYATZIS; MCKEE, 2002).

Similarly, Goleman (2001) notes that they acknowledge and reward people's strengths, accomplishments, and development, offer timely and constructive feedback and identify 
DOI: 10.14807/ijmp.v11i7.1030

people's needs for development, offer assignments that challenge and grow a person's skills. For example, a principal who recognizes the shortcomings of new teachers take it upon himself or herself to enhance their capacity and also mentor them.

The competence of influence is portrayed when a person is able to wield a range of tactics for persuasion and to handle and manage emotions effectively in other people (GOLEMAN et al., 2002). This competence enables people to be skilled at persuasion and to use complex strategies like indirect influence to build consensus and support from people. A leader with this competence is able to persuade his or her followers to support organizational goals or projects.

Inspirational leadership, also referred to as visionary leadership by Goleman (2001) is a skill which enables a person to inspire others to work together towards a common goal. In the words of Goleman et al. (2002), people with this competence inspire and create resonance with a compelling vision or shared mission. They are able to articulate and arouse enthusiasm for a shared vision and mission, step forward to lead as needed and by example regardless of their position, and guide the performance of others while holding them accountable.

The next competence in the relationship management domain is change catalyst which means initiating or managing change. It enable people to recognize the need for change and remove barriers, challenge the status quo to acknowledge the need for change, champion the change and enlist others in its pursuit, and also model the change expected of others (GOLEMAN, 2001).

A person with this competence strongly advocate for change despite opposition by compelling others to support it while they find practical ways to overcome barriers to the change. Conflict management, is spotting trouble as it is brewing and taking steps to calm those involved (GOLEMAN, 2001) which also involves negotiating and resolving disagreements among people. People with this competence are able to handle difficult people and tense situations with diplomacy and tact, understand different views of all people, bring disagreements into the open and help deescalate, and encourage debate and open discussion. They do not ignore conflict but are able to adopt peaceful methods of resolving conflicts.

The last competence in relationship management is teamwork and collaboration which means creating group synergy in pursuing collective goals and working cooperatively with peers and with others toward shared goals (GOLEMAN, 2001). This competence enables people/leaders to draw all members into active and enthusiastic participation, build team 
DOI: 10.14807/ijmp.v11i7.1030

identity and commitment, collaborate, share information and resources, spot and nurture opportunities for collaboration, and protect the group and its reputation. A person with this competence spends time forging and cementing close relationship with other employees in order to build cooperation within a group.

\subsection{Teacher Self-Efficacy}

Research on teachers' self-efficacy has attracted great attention among researchers (GUSKEY; PASSARO, 1994; TSCHANNEN- MORAN; HOY; HOY, 1998; CAPRARA et al., 2006). This is because teachers with a higher sense of efficacy exhibit greater enthusiasm for teaching (ALLINDER, 1994), are persistent when things do not go smoothly and are resilient in the face of setbacks (MILNER; WOOLFOLK HOY, 2003), and have greater commitment to teaching (COLADARCI, 1992).

Tschannen-Moran, et al. (1998) found that teachers' efficacy affect their behaviors, effort, innovation and organization, persistence, willingness to work with difficult students and commitment to the job. It would also be expected that a teacher with a strong sense of efficacy will be more willing to assist students with learning difficulties, ready to listen to parents concern, and more willing to adopt new strategies that are of benefit to student learning. Teachers' sense of efficacy influences how much effort one invest in an endeavour.

Teacher self-efficacy was defined as teacher's belief in his/her capability to organize and execute the courses of action required to successfully accomplish a specific teaching task in a particular context (TSCHANNEN-MORAN, et al., 1998). As much as believing that one has the capability to execute necessary changes to achieve the desired outcomes, one must also believe that he/she has the skills required to be successful. That is why BANDURA (1997) asserted that these beliefs were more powerful than one's actual abilities for the task at hand in influencing people's level of motivation, affective states, and actions.

The source of teachers' self-efficacy includes; mastery experiences, physiological and affective states, vicarious experiences, and social persuasion. Mastery experiences which are defined as individual past successful experiences are believed to be the most powerful source of efficacy (TSCHANNEN-MORAN et al., 1998). The reason for this is because people are most likely to believe they can be successful when they have been successful in the past (CHERNISS; GOLEMAN, 2001). If a teacher's past performance was successful it raises the efficacy beliefs but failure lowers the beliefs. For instance, a teacher whose subject excelled in the national examination will have the expectations that future performance will be better. 
DOI: 10.14807/ijmp.v11i7.1030

\subsection{Organization Commitment}

Newstrom and Davis (1997) defines organizational commitment as the degree in which an employee identifies with the organization and wants to continue active participation in it. An individual who is committed to an organization identifies with it, is proud of being a member of the organization and is unwilling to leave it. According to Colquitt et al., (2009) organizational commitment is the desire on the part of an employee to remain a member of the organization. As such a committed person strongly identifies with and feels a part of the organization which he/she works for and have a feeling of loyalty towards his/her organization.

Despite these many definitions, there is no agreement on the definition of OC. Hence Meyer and Allen (1991) suggests that one must specify the definition he or she uses to avoid confusion. The duo developed the most widely accepted and most dominant multidimensional commitment framework referred to as the three-component model (TCM). This model consist of three dimensions namely; affective commitment, continuance commitment, and normative commitment.

They clarify that the three dimensions of commitment are distinguishable components, rather than three separate types of commitment. These can be related to each other in different ways and that an individual can experience different levels of the three forms of commitment. The three have received considerable interest from researchers and have been tested in different empirical settings (MEYER et al., 2002; COHEN, 2007; SOLINGER; VAN OLFFEN; ROE, 2008). The main reason for this, Meyer et al., (2002) note is the belief that three-component model relate negatively to turnover, but relate differently to measures of other work-relevant behaviors.

However, it is important to note that $\mathrm{AC}$ was found to be the most reliable and strongly validated dimension and correlated with the widest range of behavioral criterion variables (MEYER; HERSCOVITCH, 2001). Affective commitment (AC) is employees' emotional attachment to, identification with, and involvement in the organization (SOLINGER, et al., 2008). Continuance commitment (CC) refers to an awareness of the costs associated with leaving the organization (MEYER; ALLEN, 1997).

Employees or teachers who perceive that the cost of leaving the organization/school is greater than the cost of staying therefore remain with the organization because they need to. Normative commitment (NC) refers to employees' feelings of obligation to the organization. Therefore, employees' stay with the organization because they think it is the right and 
DOI: 10.14807/ijmp.v11i7.1030

acceptable thing to do. Teachers with high levels of normative commitment stay with the organization/school because they feel they ought to, which may be attributed to the need to repay for the treatment they receive from their school.

Many other forms of organizational commitment have been examined (COHEN, 2006; MATHIEU; ZAJAC, 1990; COHEN 1999). For example, COHEN (2006) studied organizational and occupational commitment whereas Mathieu and Zajac, (1990) referred to attitudinal and calculative commitment. Allen and Meyer (1990) and Meyer and Allen (1997) studies found that OC is a multi-dimensional construct. COHEN (1999) studied affective organizational commitment, continuance organizational commitment, career commitment, job involvement and work ethic endorsement. Since as an employee relate with the organization can express different degree of each of the constructs, this study will adopt Meyer and Allen (1991) TCM construct.

\subsection{Relationship Management and Organization Commitment}

Leadership is about influence and for leaders to positively influence their subordinates they must possess the necessary skills and abilities. Research indicate that emotionally intelligent leaders tend to influence not only their subordinates' emotions and actions (GEORGE, 2000) but also their organizational commitment (Long, SHANMUGAM; YUSOFF, 2014: QURESHI et al., 2015). A growing body of research also indicate that a leader's mood and emotions can influence their subordinate emotions either positively or negatively (VOLMER, 2012; GEORGE, 2000) which in turn triggers positive organizational outcome and personal relationship.

Recognition of one's emotions and those of others promote good relationship between a leader and the subordinates thus resulting in organizational commitment among the employees. As a result, employees trust them and feel good about working with such leaders (COETZEE; PAUW, 2013). A leader who recognizes his or her emotions and that of others can tell when a change in an organization has caused anxiety among employees and therefore try to resolve the problem.

At the same time leaders who are aware of their emotions and those of others are more likely to react to a problem in a more controlled manner and may be more accommodative to different views of the subordinates. By managing conflict and encouraging supportive member interaction, the leader creates a supportive environment for the members (PRATI et al., 2003). Understanding and regulation of one's emotions as well as understanding other's emotions are 
DOI: 10.14807/ijmp.v11i7.1030

factors that affect interpersonal relations which means that leaders may affect the OC of their employee (SALAMI, 2008).

\subsection{Self-Efficacy and Organization Commitment}

Numerous researches have been carried out to establish whether relationship exist between self-efficacy and organization commitment (CAPRARA, et al., 2006; SALEEM; SABA; ADNAN, 2013, LUTHANS; ZHU; AVOLIO, 2006). These studies observed a positive relationship between self-efficacy and organizational commitment. According to Schwarzer and Hallum (2008) when setbacks occur, self-efficacious individuals recover quickly and maintain commitment to their goals. They approach challenging situations with confidence while increasing their efforts which makes them successful. Tschannen-Moran, et al. (1998) indicated that teachers with a strong sense of efficacy exhibit greater enthusiasm for teaching, have greater commitment to the profession, and are more likely to remain in the classroom. On the contrary low efficacious people see difficult situations as threat and quickly give up in case of failure.

According to Luthans, et al., (2006) employees with a high level of general self- efficacy are more likely to be committed to their organization. Tsai, Tsai, and Wang (2011) study on the relationship between leadership style, emotional intelligence, self-efficacy and organizational commitment in the Banking Industry in Taiwan found that employees selfefficacy results in a significant positive influence on organizational commitment. At the school level, perceived self-efficacy beliefs have been powerfully related to meaningful outcomes such as teachers' persistence, enthusiasm, commitment and instructional behavior (TSCHANNEN-MORAN; WOOLFOLK HOY, 2001). Teachers’ belief about their teaching abilities will affect their teaching behavior such as perseverance in the face of obstacles and even commitment to teaching.

Coladarci (1992) study to examine the degree to which teachers' sense of efficacy predicted commitment to teaching revealed a significant relationship between self-efficacy and OC. According to the results general and personal efficacy emerged as the two strongest predictors of teaching commitment, along with teacher-student ratio, school climate, and sex.

\section{METHODOLOGY}

\subsection{Research Design}

This study applied survey research design which was cross-section in nature using questionnaire to collect data. Saunders, Lewis and Thornhill (2012) posits that survey using 
DOI: 10.14807/ijmp.v11i7.1030

questionnaires are popular as they allow the collection of standardized data from a sizeable population in a highly economic way, allowing easy comparison.

\subsection{Study Population and Sample}

The population for this study was all the 560 principals and all teachers in secondary schools in Nairobi, Machakos, Kajiado, and Kiambu counties in Kenya. The sample size adopted for this study was 120 principals and four teachers from each selected school which gave a total of 480 teachers. Simple random sampling was used to select the principals and teachers from each school. Stratified sampling was used to group the principals into male and female so as to have a representative of each gender and to select the number of principals in the selected four counties. Kothari (2004) notes that stratified sampling technique is applied in case the population from which a sample is to be drawn does not constitute a homogeneous group.

\subsection{Data Collection Methods}

Data collection method for this study was by use of questionnaire.

Relationship Management Questionnaire. We measured principals' RM using Emotional Competency Inventory (ECI) v.2 (GOLEMAN; BOYATZIS, 2002). ECI is a 360degree or multi-rater assessment that combines self, subordinate, peer, and supervisor rating on the EI competencies (GOWING, 2001). In this study, teachers rated the principals' RM. Research indicates that self-reports are subject to reporting bias, especially in organizational contexts where people might be motivated to fake good (ROSETE; CIARROCHI, 2005). This is because there is often a significant difference between self and other ratings (GOWING, 2001; NZOMO, 2012; WOLFF, 2005).

Twelve items were composed from the six competencies of RM that is influence, developing others, inspirational leadership, change catalyst, conflict management, and teamwork and collaboration. This is because using one or two competencies from each of the clusters is far more effective than using all of the competencies within a cluster (SEAL; SASS; BAILEY; LIAO-TROTH, 2006).” A 5-point Likert scale ranging from “Strongly Agree” to "Strongly Disagree” was used to collect data.

Self-efficacy Questionnaire. The Teacher Sense of Efficacy Scale (TSCHANNENMORAN; WOOLFOLK; HOY, 2001) which consists of 12 items was used to measure teachers' self-efficacy. This is because it is the most widely used and accepted measure (FIVES; BUEHL, 2010; RODRÍGUEZ et al., 2014). Tschannen-Moran, Woolfolk and Hoy 
DOI: 10.14807/ijmp.v11i7.1030

(2001) posits that this measure is of reasonable length and useful for exploring the construct of teacher efficacy.

Organizational Commitment Questionnaire. We measured teachers' OC using the MEYER; ALLEN; SMITH, (1993) TCM Employee Commitment Survey designed to measure the three dimensions of organizational commitment (AC, CC and NC). To avoid confusion the term organization was replaced by school and in some instance with the term job.

\subsection{Data Analysis}

The researcher applied descriptive statistics, independent sample t-test, and multiple regression methods to analyze data. To analyze descriptive statistics, means, frequencies, percentages, and standard deviation were used. Independent sample t-test was used to test whether there were differences between gender and the study variables. Banda (2018) posits that independent samples $t$-test tells the researcher whether there is a statistically significant difference in the mean scores for the two groups. Coefficient of correlation was computed to determine the relationship between the study variables. Regression analysis was also used to test the extent to which principals' relationship management significantly predicts teachers' OC.

The regression model for this study was:
a) $Y=\beta_{0}+\beta_{x} X+\varepsilon$
b) $Y=\beta_{0}+\beta_{X} X+\beta_{z} Z+\varepsilon$
c) $Y=\beta_{0}+\beta_{X} X+\beta_{Z} Z+\beta_{x Z} X Z+\varepsilon$

\section{5. $\quad$ Results}

\subsubsection{Profile of the Participants}

The respondents comprised of 102 secondary school principals and 408 teachers. The results of the study indicate that $52 \%$ of the teachers were female and $48 \%$ were male, $42.2 \%$ of the principals were female while $57.8 \%$ were male. The ages of the respondents ranged from 25 years to above 50 years ( $47.1 \%$ of the principals and $12.5 \%$ of teachers were 50 and above years of age). Most of the respondents (55.9\% of the principals and $73.3 \%$ of teachers) were degree holders. 
DOI: 10.14807/ijmp.v11i7.1030

\subsubsection{Independent T-Test for the relationship between Gender and Study Variables}

To test whether there were differences between gender and the study variables an independent sample $t$-test was conducted (Table 1). In terms of teachers' self-efficacy the study revealed that the mean difference is significant (mean difference $=0.08, \mathrm{t}=-2.622, \mathrm{df}=406$, $\mathrm{p}$-value $=0.009)$. Female teachers have higher self-efficacy than the male. For OC the mean difference is not significant (mean difference $=-0.06, \mathrm{t}=-1.613, \mathrm{df}=406, \mathrm{p}$-value $=0.107$ ). This is consistent to Turunen (2011) study on employment and OC among employees in Finland, Germany, Great Britain, Spain and Sweden that found that women displayed strong commitment than men in all the comparison countries. The mean difference for principals' RM as rated by the teachers is significant ((mean difference $=-0.08, \mathrm{t}=-2.340, \mathrm{df}=406, \mathrm{p}$-value $=$ 0.02 ) as the female had a higher RM index.

Table 1: Independent T-Test for the relationship between Gender and Study Variables Group Statistics

\begin{tabular}{llllrc}
\hline & Gender & $\mathrm{N}$ & Mean & Std. Deviation & $\begin{array}{c}\text { Std. Error } \\
\text { Mean }\end{array}$ \\
& & & & & \\
Self Efficacy:Teacher & Male & 196 & 2.9524 & .27308 & .01951 \\
& Female & 212 & 3.0326 & .33855 & .02325 \\
Organizational Commitment of & Male & 196 & 2.8262 & .36511 & .02608 \\
teacher & Female & 212 & 2.8866 & .38899 & .02672 \\
Relationship Management:T & Male & 196 & 3.2959 & .32305 & .02308 \\
& Female & 212 & 3.3781 & .38152 & .02620
\end{tabular}

\section{Independent Samples Test}

\section{Levene's}

Test for

Equality of

Variances

Self Equal

Efficacy:Teacher variances assumed

Equal variances not assumed

Organizational Equal Commitment of variances teacher assumed

Equal variances not assumed t-test for Equality of Means

$95 \%$

Confidence Interval of the

Sig.

(2- Mean Std. Error Difference

$\mathrm{F} \quad$ Sig. $\mathrm{t}$ df tailed) Difference Difference Lower Upper
$\begin{array}{llr}3.140 & .077 & - \\ & 2.622\end{array}$
406
$.009-.08024$
$.03060-.14041$
.02008
$2.644^{-} 398.777$
$.009-.08024$
$.03035-.13991$
.02058

$\begin{array}{llrlllllll} & 308 & .579 & 1.613 & 406 & .107 & -.06038 & .03743 & -.13395 & .01320\end{array}$

$1.617^{-} 405.905 \quad .107 \quad-.06038$

$.03733-.13377 .01302$ 
INDEPENDENT JOURNAL OF MANAGEMENT \& PRODUCTION (IJM\&P)

http://www.ijmp.jor.br

v. 11, n. 7, November-December 2020

ISSN: 2236-269X

DOI: 10.14807/ijmp.v11i7.1030

Relationship

Equal

Management:T variances

assumed

4.940

Equal

variances not

assumed

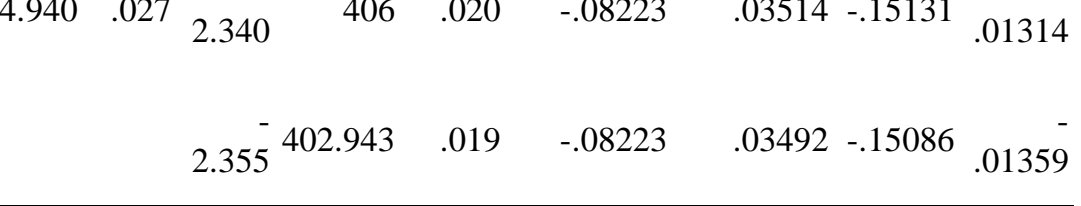

\subsection{Correlation Analysis}

To establish whether there exists relationship between the study variables, a correlation matrix was run. Correlation measures the relationship between variables in order to identify whether they are positively or negatively related or not related in any way. Pearson ProductMoment Correlation Coefficient designated $r$, is used for correlation analysis. Pearson correlation $r$ usually measures the strength of the relationship between the independent and dependent variables, while the significance is shown by the $p$-value (where $p=0.05$ or 0.01 ).

According to Obilor et al. (2018) the larger the $p$-value, the stronger the relationship whereas a smaller $p$-value denotes more significant relationship. Mason and Lind (1999) note that Pearson's $(r)$ can assume any value from -1.00 to +1.00 . A correlation coefficient of -1 and +1 indicates perfect negative and perfect positive correlation respectively. If Pearson's $r$ is zero it means there is absolutely no association or there is zero correlation between the variables.

Table 2 shows the correlation coefficient between principals’ RM and teachers' OC was positive ( $r=0.346, p$-value $<0.001$ ). Teachers' self-efficacy posted a positive and moderate correlation with principals' RM ( $\mathrm{r}=0.468, p$-value $<0.001)$ but the correlation between teachers' OC and self-efficacy was weak but positive $(r=0.163$, $p$-value $=0.001$ ).

Table 2: Correlation Matrix for the Study Variables

\begin{tabular}{|c|c|c|c|c|}
\hline & & $\mathbf{Y}$ & $\mathbf{X}$ & $* \mathrm{Z}$ \\
\hline & & Teachers Commitment & Relationship & Self-efficacy: Teacher \\
\hline \multirow[t]{3}{*}{ Y } & Pearson Correlation & 1 & & \\
\hline & $\begin{array}{l}\text { Sig. } \\
\text { (2-tailed) }\end{array}$ & & & \\
\hline & $\mathrm{N}$ & 408 & & \\
\hline \multirow[t]{3}{*}{$\mathrm{X}$} & Pearson Correlation & $.346^{* *}$ & 1 & \\
\hline & $\begin{array}{l}\text { Sig. } \\
\text { (2-tailed) }\end{array}$ & .000 & & \\
\hline & $\mathrm{N}$ & 408 & 408 & \\
\hline \multirow[t]{3}{*}{$\mathrm{Z}$} & Pearson Correlation & $.163^{* *}$ & $.468^{* *}$ & 1 \\
\hline & $\begin{array}{l}\text { Sig. } \\
\text { (2-tailed) }\end{array}$ & .001 & .000 & \\
\hline & $\mathrm{N}$ & 408 & 408 & 408 \\
\hline
\end{tabular}

Self-Efficac Teacher 
INDEPENDENT JOURNAL OF MANAGEMENT \& PRODUCTION (IJM\&P)

http://www.ijmp.jor.br

v. 11, n. 7, November - December 2020

ISSN: 2236-269X

DOI: 10.14807/ijmp.v11i7.1030

Key: $Y=$ Organizational Commitment; $\mathrm{X}=$ Relationship Management; Z=Self-Efficacy.

\subsection{Regression Results on the relationship between Principals' Relationship Management and Teachers’' Organizational Commitment}

The study hypothesized that:

- $\mathbf{H}_{01}$ : There is no significant effect of principal's relationship management on the OC of teachers

The standardized coefficient for principals' RM was significant $\left(\beta_{\mathrm{x}}=0.346, \mathrm{t}=7.419\right.$, p-value<0.001) which implies that for one unit increase in principals' RM, organizational commitment for teachers increases by 0.346 . Relationship management explains $12 \%\left(r^{2}=0.119\right)$ of the variation of organizational commitment implying that other factors outside relationship management explain $88 \%$ of variation in organization commitment. Since $\beta_{\mathrm{x}}$ is significantly different from zero, the null hypothesis is rejected $\left(\mathrm{H}_{04}: \beta_{\mathrm{x}}=0\right)$ and concludes that principals’ RM significantly affect teachers' OC. This means that with improved principals’ RM, teachers OC would greatly improve.

Table 3: Regression Results for the Relationship between Principals' Relationship Management and Teachers' Organizational Commitment Model Summary

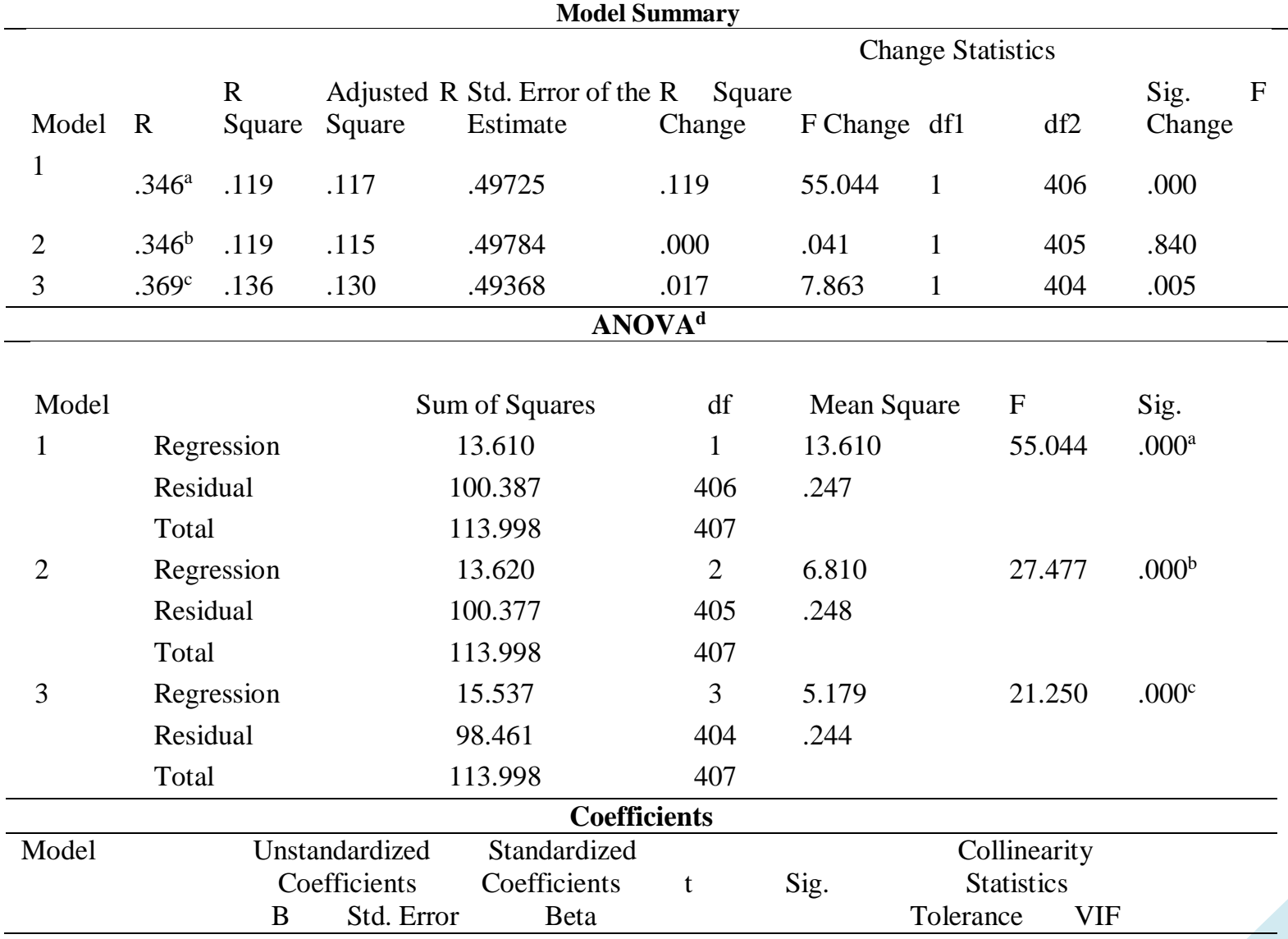


ISSN: 2236-269X

DOI: 10.14807/ijmp.v11i7.1030

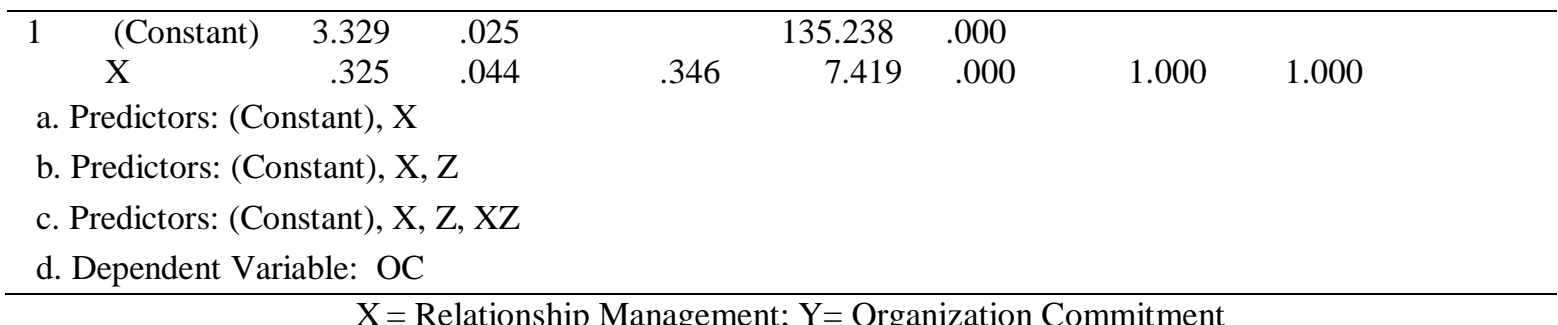

\subsection{Moderating Effect of Self-Efficacy on the Relationship between Principals'} Relationship Management and Teachers' Organizational Commitment

The study hypothesized that:

- Ho1b: Teachers' self-efficacy has no significant moderating effect on the relationship between principals’ relationship management and teachers’ OC.

The following models were fitted to test the hypothesis:

a) Model 1: $\mathrm{Y}=\beta_{0}+\beta_{\mathrm{X}} \mathrm{X}+\varepsilon$

b) Model 2: $Y=\beta_{0}+\beta_{\mathrm{x}} \mathrm{X}+\beta_{\mathrm{z}} \mathrm{Z}+\varepsilon$

c) Model 3: $Y=\beta_{0}+\beta_{\mathrm{X}} \mathrm{X}+\beta_{\mathrm{Z}} \mathrm{Z}+\beta_{\mathrm{xz}} \mathrm{XZ}+\varepsilon$

where $\mathrm{X}=$ Relationship management (RM), Z= Self-efficacy, XZ= Interaction Term

On the moderating effect of Z (self-efficacy) on the relationship between principals’ RM and teachers' OC $(\mathrm{Y})$, all the three models were significant $(\mathrm{F}(1,406)=55.044$, p-value $<0.001$; $\mathrm{F}(2,405)=27.477, \mathrm{p}$-value $<0.001 ; \mathrm{F}(3,404)=21.250$, $\mathrm{p}$-value $<0.001)$. From the model summary, the F change for RM was significant which implies that principals' RM significantly affects teachers' OC. On adding the Z (self-efficacy) as a predictor to the model containing $\mathrm{RM}$, the $\mathrm{F}$ change reduced drastically and was not significant (F2 Change $=0.041$, pvalue $=0.840$ ).

With the introduction of the interaction term (XZ) to this model, it improved substantially and was significant (F3 Change=7.863, p-value=0.005). The implication of this is that self-efficacy moderated the relationship between principals' RM and teachers' OC. Hence we reject the null hypothesis and conclude that teachers' self-efficacy moderate the relationship between principals’ RM and teachers’ OC.

\section{DISCUSSION AND CONCLUSION}


DOI: 10.14807/ijmp.v11i7.1030

There seems to be no consensus among researchers on the effect of relationship management on OC from previous studies. While some studies demonstrate a positive relationship between the two, others argue in the contrary, stating that there is no relationship or an inconsistent relationship between these two variables (SHOOSHTARIAN; AMELI; AMINILARI, 2013; QURESHI et al., 2015; VOLMER, 2012).

This study hypothesized that there is no significant effect of principal's RM on the OC of teachers. The findings of this study indicate that there is a significant relationship between principals' RM and teachers OC. Principals' RM which involves being aware of one's emotions and those of others in order to build strong relationships significantly predicted of teachers' OC. The standardized coefficient for principals' RM was significant $\left(\beta_{\mathrm{x}}=0.346, \mathrm{t}\right.$ $=7.419$, $\mathrm{p}$-value $<0.001) \mathrm{p}$-value $<0.001$ ) which implies that for one unit increase in principals' relationship management, teachers 'organizational commitment increases by about 0.325 .

Since principal' RM significantly correlated to teachers' OC, the null hypothesis is rejected. This implies that recognition of one's emotions and those others promote good relationship between principals and the teachers thus resulting in increased OC among the teachers. This is supported by affective events theory (AET) and is consistent with Volmer (2012) and George (2000) findings that leader's mood and emotions can influence their subordinate emotions either positively or negatively which in turn triggers positive organizational outcome.

This is because a leader who possesses relationship management skill acknowledges and reward people's strengths, accomplishments, and offer timely and constructive feedback (GOLEMAN, 2001). This findings also corroborate with Long, et al. (2014); Aghabozorgi, et al. (2014) that leader's emotional intelligence significantly affect organizational commitment of their subordinates. This means that teachers' employer (TSC) needs to put more emphasize on training of RM among principals in secondary schools in Kenya.

The result on the moderating effect of teachers' self-efficacy on the relationship between principals' RM and teachers' OC was statistically significant. This implies that teachers' selfefficacy moderated between principals' RM and teachers' OC; hence the null hypothesis was rejected. This is consistent to Coladarci (1992) findings that teachers' self-efficacy has been linked to commitment towards one's profession. Teachers' efficacy or belief in one's capability to execute a task affects their behavior, effort and in the long run their commitment to the job. 
DOI: 10.14807/ijmp.v11i7.1030

\subsection{Implication for Practice}

The results of this study have important implications for management practice. Given that most research on principals' RM and teachers' OC has been conducted outside Kenya (CARMELI, 2003; KHALILI, 2011; COETZEE; PAUW, 2013), findings from our study demonstrate that the effects of these two variables are not limited to only those other countries. Little research has explored the moderating role of self-efficacy in the relationship between principals' RM and teachers' OC, therefore this study makes a significant contribution to the advancement of knowledge in academic sector.

\subsection{Recommendations of the Study}

Based on these results; the study recommends that RM development programmes should be part of education management training programmes for principals' and deputies aimed at building and enhancing their RM. Better still this may be included in curriculum of institutions that train student teachers such as universities in order to enhance their RM. Teacher employer should also include RM as an important skill during recruitment of new principals or teachers.

The results shows that teachers' self-efficacy is high and the main source of their efficacy was mastery experience. Efficacy beliefs influence self-motivation of workers and determine how much effort they invest in a task (BANDURA, 1997). The study recommends that teachers' employer should provide new teachers with guided mastery experiences and come up with ways of building their self-efficacy such as job enrichment.

Job enrichment help to provide immediate evaluation of their work hence making people work harder as they find their work more exciting. The school principals should be encouraged to give frequent verbal encouragement to the teachers which will help them overcome self-doubt and inturn improve their self-efficacy.

\subsection{Areas of Further Research}

Limited research if any has been conducted in Kenya in relation to the effects of principals’ RM on teachers' OC. The study confined itself to Nairobi, Machakos, Kajiado, and Kiambu counties in Kenya, more research could be carried out in other counties. Since principals' RM significantly influences teachers' OC, this study recommends that more research could be carried out in other sectors on the effects of leaders' RM on employees OC. To fully understand principals OC, further research need to be carried out on perceived organizational commitment of principals by teachers. 
Tschnannen and Gareis (2007) argues that Principal self-efficacy is important for modern principals as it offers insight into the complex, challenging, and critically important role associated with this position in present-day schools. Further research could be carried out on the effect of principals' self-efficacy on their OC. Similarly, research could also be done on the impact of principals' self-efficacy on students' achievements.

\subsection{Limitations of the Study}

This study was not without limitations. First, this study covered Nairobi and the surrounding counties of Kajiado, Machakos, and Kiambu as the areas have a diverse population, as such generalizing the results of this study to the whole country would be limited. Second, the fact that the study was cross-sectional in nature rather than longitudinal it did not allow affirmative causal explanations.

There was also suspicion among the respondents about the intentions of the research and the use of the collected data. This was mitigated by re-assuring the teachers that the information would not get to the principals, that it was confidential and would be used purely for academic purposes.

\section{REFERENCES}

ADEDOYIN, O .O. (2010) Factor-analytic study of teachers' perceptions on self efficacy in Botswana junior secondary schools: implication for educational quality. European Journal of Educational Studies, v. 2, n. 2.

AGHABOZORGI, A.; MEHNI, M.; ALIPOUR, O.; AZIZI, B. (2014) Impact of emotional intelligence on organizational commitment of nurses in the public hospital of Sanandaj. Indian Journal of Fundamental and Applied Life Science, v. 4, n. 3, p. 120-7.

ALBDOUR, A.; ALTARAWNEH, I. (2014) Employee engagement and organizational commitment: Evidence from Jordan. International Journal of Business, v. 19, n. 2, p 10834346.

ALLEN, N. J.; MEYER, J. P. (1990) The measurement and antecedents of affective continuance, and normative commitment to the organization. Journal of Occupational Psychology, n. 63, p. 1-18.

ALLINDER, R. M. (1994) The relationship between efficacy and instructional practices of special education teachers and consultant. Teacher Education and Special Education, $n$. 17, p. 86-9.

BANDA, G. (2018) A brief review of independent, dependent and one sample t-test.

International Journal of Applied Mathematics and Theoretical Physics, v. 4, n. 2, p. 50-4

BANDURA, A. (1997) Self-efficacy: the exercise of control. In TSCHANNEN-MORAN, M.; GAREIS, C. R. (2007) Cultivating principals' sense of efficacy: support that matter. Journal of School Leadership, n. 7, p. 89-25. 
CAPRARA, G. V.; BARBARANELLI, C.; STECA, P.; MALONE, P. S. (2006) Teachers' self-efficacy beliefs as determinants of job satisfaction and students' academic achievement: a study at the school level. Journal of School Psychology, n. 44, p. 473-17.

CARMELI, A. (2003) The relationship between emotional intelligence and work attitudes, behavior and outcomes: An examination among senior managers. Journal of Managerial Psychology, v. 18, n. 8, p. 788-25.

CHERNISS, C.; GOLEMAN, D. (2001) The Emotionally intelligent workplace: how to select for, measure, and improve emotional intelligence in individuals, groups, and organizations. San Francisco: Jossey-Bass.

COETZEE, W.; PAUW, D. (2013) Staff perception of leader emotional competency as a predictor of satisfaction with retention factors. Journal of Psychology in Africa, v. 23, n. 2, p. 177-9.

COHEN, A. (1999) Relationships among Five Forms of Commitment: An Empirical Assessment. Journal of Organizational Behavior, n. 20, p. 285-23.

COHEN, A. (2007) Commitment before and after: an evaluation and reconceptualization of organizational commitment. Human Resource Management Review, n. 17, p. 336-18.

COHEN, A. (2006) The relationship between multiple commitment and organizational citizenship behavior in Arab and Jewish Culture. Journal of Vocational Behavior, n. 69, p. 105-13.

COLADARCI, T. (1992) Teachers' sense of efficacy and commitment to teaching. Journal of Experimental Education, v. 60, n. 4, p. 323-14.

COLQUITT, J.; LEPINE, J.; WESSON, M. (2009) Organizational behavior: improving performance \& commitment in the workplace. New York: McGraw-Hill.

GEORGE, J. M. (2000) Emotions and leadership: the role of emotional intelligence. Human Relations, n. 53, p. 1027-28.

GOLEMAN, D.; BOYATZIS, R.; MCKEE, A. (2002). Primal leadership: realizing the power of emotional intelligence. Harvard Business School Press: Boston.

GOLEMAN, D. (2001) An EI-based theory of performance. In CHERNISS, C.; GOLEMAN, D. (Ed), The Emotionally Intelligent Workplace: How to Select for, Measure, and Improve Emotional Intelligence in Individuals, Groups, and Organizations. San Francisco: Jossey-Bass.

GOLEMAN, D. (1998 b) What makes a leader? Harvard Business Review, n. 76, p. 93-9.

GOWING, M. K. (2001) Measurement of individual emotional competence. IN CHERNISS, C.; GOLEMAN, D. (Eds.) The emotionally intelligence workplace: How to select for, measure, and Jossey-Bass.improve emotional intelligence in individuals, groups, and organizations. San Francisco, CA:

GUSKEY, T. R; PASSARO. P. D. (1994) Teacher efficacy: a study of construct dimensions. American Educational Research Journal, n. 31, p. 627-16.

HE, P. (2008) An Investigation of the antecedents and consequences of affective commitment in a U.S. hospitality organization. Unpublished Ph.D Dissertation. Virginia Polytechnic Institute and State University.

JAROS, S. (2007) Meyer and Allen Model of Organizational Commitment: Measurement Issues. The Icfai 8 Journal of Organizational Behavior, v. 6, n. 4, p. 7-18. 
KENYA NATIONAL UNION OF TEACHER (2015). Report on Trends of the Needs of Teachers in Public Schools in Kenya.

KHALILI, A. (2011) Examining the relevance of emotional intelligence and organizational commitment among employees of small and medium enterprise in private sector.

International Journal of Business and Management, v. 6, n. 12, ISSN 1833-3850, E-ISSN 1833-8119.

LONG, C. S.; SHANMUGAM, C. S.; YUSOFF, R. Md. (2014) Attaining organizational commitment through leaders' emotional intelligence: A case study in Malaysia. World Applied Sciences Journal, v. 32, n. 7, p. 1284-1288. DOI: 10.5829/idosi.wasj.2014.32.07.1975

LUTHANS, F.; ZHU, W.; AVOLIO, B. J. (2006) The impact of efficacy on work attitudes across cultures. Journal of World Business, n. 41, p. 121-11.

MACHIO, J. (2011) Scrap teachers' proficiency test, KNUT Tells State. In MUGWERU, W. (2013) Promotion of secondary school teachers by gender, experience and school type, a case in Kenya. Middle Eastern \& African Journal of Educational Research, v. 6, p. 24.

MASON, R. D.; LIND, D. A. (1999) Statistical techniques in business and economics. Boston: McGraw Hill.

MATHIEU, J. E.; ZAJAC, D. M. (1990) A review and meta-analysis of antecedents, correlates and consequences of organizational commitment. Psychological Bulletin, n. 108, p. 171-23.

MATTHEWS, G.; ZEIDNER, M.; ROBERTS, R. D. (2012). Emotional Intelligence: A Promise Unfulfilled? Japanese Psychological Research, v. 54, n. 2, p. 105-22.

MAYER, J. D.; SALOVEY, P. (1990) Emotional intelligence: imagination, Cognition and Personality. In ZEIDNER, M.; MATTHEWS, G.; ROBERTS, R. D. (2004) Emotional intelligence in the workplace: a critical review. Applied Psychology: An International Review, v. 53, n. 3, p. 371-28.

MAYER, J. D.; SALOVEY, P. (1997) What is emotional intelligence? In Mayer, J. D.; Salovey, P.; Caruso, D. R. (2008) Emotional intelligence: new ability or eclectic traits? American Psychologist, v. 63, n. 6, p. 503-14.

MEYER, P. J.; ALLEN, J. N. (1997) Commitment in the workplace: theory, research, and application. In COHEN, A. (2006) the relationship between multiple commitment and organizational citizenship behavior in Arab and Jewish culture. Journal of Vocational Behavior, n. 69, p. 105-13.

MEYER, J. P.; ALLEN, N. J. (1991) A three-component conceptualization of organizational commitment. Human Resource Management Review, v. 1, n. 1, p. 61-28.

MEYER, J. P.; ALLEN, N. J.; SMITH, C. A. (1993) Commitment to organizations and Occupations: Extension and test of a three-component conceptualization. Journal of Applied Psychology, n. 78, p. 538-13.

MEYER, J. P.; ALLEN, N. J. (2004) TCM employee commitment survey academic users guide. The University of Western Ontario.

MEYER, J. P.; HERSCOVITCH, L. (2001) Commitment in the workplace: toward a general model. Human Resources Management Review, n. 11, p. 299-25. 
MEYER, J. P.; PARFYONOVA, N. M. (2010) Normative commitment in the workplace: a theoretical analysis and re-conceptualization. Human Resource Management, n. 20, p. 28311 .

MEYER, J. P.; STANLEY, D. J.; HERSCOVITCH, L.; TOPOLNYTSKY, L. (2002) Affective, continuance, and normative commitment to the organization: a meta-analysis of antecedents, correlates, and consequences. Journal of Vocational Behavior, v. 61, n. 1, p. 20-12.

MILNER, H. R.; WOOLFOLK HOY, A. (2003) A case study of an African American teacher's self-efficacy, stereotype, threat, and persistence. Teaching and Teacher Education, n. 19, p. 263-13.

MOWDAY, R. T. (1998) Reflections on the study and relevance of organizational commitment. Human Resource Management Review, v. 8, n. 4, p. 387-14.

MURPHY, D. P. (2013) An examination into the relationship between teacher efficacy and organizational commitment of special education teachers. Thesis ( $\mathrm{PhD}$ in Education Leadership). Boston: Massachusetts.

NEWSTROM, J. W.; DAVIS, K. (1997) Organizational behavior: human behavior at work. New York: McGraw Hill.

NZOMO, L. N. (2012) Relationship between principals' emotional intelligence and student learning achievement in public secondary school in Nairobi County Kenya. Thesis (Ph.D in Education), Nairobi: Kenya.

OBILOR, E.; AMADI, E.(2018) Test for significance of Pearson's correlation coefficient. International Journal of Innovative Mathematics, Statistics \& Energy Policies v. 6, n. 1, p. 11-12.

PRATI, L. M.; DOUGLAS, C.; FERRIS, G. R.; AMMETER, A. P.; BUCKLEY, M. R. (2003) Emotional intelligence, leadership effectiveness, and team outcomes. The

International Journal of Organizational Analysis, v. 11, n. 1, p. 21-19.

QURESHI, I. A.; ALI, R.; RAZA, H.; WHITTY, M. (2015) The Impact of leader's emotional intelligence on employee commitment: an empirical study in the sports industry of Sialkot, Pakistan. Journal of Business and Management, v. 17, n. 1, p. 125-9.

RHOADES, L.; EISENBERGER, R.; ARMELI, S. (2001) Affective commitment to the organization: the contribution of perceived organizational support. Journal of Applied Psychology, v. 86, n. 5, p. 825-11.

ROSETE, D.; CIARROCHI, J. (2005) Emotional intelligence and its relationship to workplace performance outcomes of leadership effectiveness. Leadership and Organization Development Journal, v. 26, n. 5, p. 388-11.

SALAMI, S. (2008) Demographic and psychological factors predicting organizational commitment among industrial workers. Anthropologist, v. 10, n. 1, p. 31-9.

SALEEM, A.; SABA, G.; ADNAN, A. (2013) Self-efficacy and optimism as predictors of organizational commitment among bank employees. International Journal of Research Studies in Psychology, ISSN: 2243-7781.

SAUNDER, M.; LEWIS, P.; THORNHILL, A. (2012) Research methods for business students $\left(6^{\text {th }}\right.$ Ed.). London: Pearson. 
SCHWARZER, R.; HALLUM, S. (2008) Perceived teacher self-efficacy as a predictor of job stress and burnout: mediation analyses. Applied Psychology: An International Review, n. 57, p. 152-19.

SEAL, C. R.; SASS, M. D.; BAILEY, J. R.; LIAO-TROTH, M. (2006) Integrating the emotional intelligence construct: the relationship between emotional ability and emotional competence. Organization Management Journal, n. 6, p. 204-10.

SHOOSHTARIAN, Z.; AMELI, F.; AMINILARI, M. (2013) The effect of labour's emotional intelligence on their job satisfaction, job performance and commitment. Iranian Journal of Management Studies (IJMS), v. 6, n. 1, p. 29-44.

SOLINGER, O. N.; VAN OLFFEN, W.; ROE, R. A. (2008) Beyond the three-component model of organizational commitment. Journal of Applied Psychology, v. 93, n. 1, p. 70-13.

TSAI, M-T.; TSAI, C-L.; WANG, Y-C (2011) A study on the relationship between leadership style, emotional intelligence, self-efficacy and organizational commitment: a case study of banking industry in Taiwan. African Journal of Business Management, v. 5, n. 13, p. 5319-10.

TSCHANNEN-MORAN, M.; GAREIS, C. R. (2007) Cultivating principals' sense of efficacy: support that matter. Journal of school leadership, n. 7, p. 89-25.

TSCHANNEN-MORAN, M; GAREIS, C. R. (2004) Principals’ sense of efficacy: assessing a promising construct. Journal of Educational Administration, v. 42, n. 5, p. 573-12.

TSCHANNEN-MORAN, M.; HOY, A. W. (2001) Teacher Efficacy: Capturing an Elusive Construct. Teacher and Teacher Education, n. 17, p. 783-22.

TSCHANNEN-MORAN, M.; HOY, A. W.; HOY, W. K. (1998) Teaching efficacy: its meaning and measure. Review of Educational Research, v. 68, n. 2, p. 202-46.

TURUNEN, T. (2011) Commitment to employment and organization: Finland in a European Comparison. Research on Finnish Society, n. 4, p. 55-11.

VOLMER, J. (2012). Catching leaders’ mood: contagion effects in teams. Administrative Sciences, n. 2, p. 203-23.

WOLFF, S. B. (2005) Emotional Competence Inventory (ECI) Technical Manual. Hay Group. McClelland Center for Research and Innovation. Philadelphia, PA.

ZEIDNER, M.; MATTHEWS, G.; ROBERTS, R. D. (2004) Emotional intelligence in the workplace: a critical Review. Applied Psychology: An International Review, n. 53, p. 37128

ZEIDNER, M.; ROBERTS, R.; MATTHEWS, G. M. (2002) Can emotional intelligence be schooled? A critical review. In ZEIDNER, M.; MATTHEWS, G.; ROBERTS, R. D. (2004) Emotional intelligence in the workplace: a critical review. Applied Psychology: An International Review, v. 53, n. 3, p. 371-28. 